\section{Legemiddelindustrien som mafia}

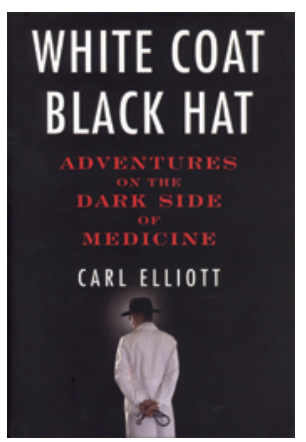

\section{Carl Elliott \\ White coat, black hat}

Adventures of the dark side of medicine. $213 \mathrm{~s}$. Boston, MA: Beacon Press, 2010. Pris USD 25 ISBN 978-0-8070-6142-8

Carl Elliott er ein amerikansk lege som kjente ubehag ved å bli lege, som søkte over mot filosofien, og som har enda opp som professor i etikk ved University of Minnesota. Han har skrive gode bøker om bioetikk, kultur og identitet og har eit kritisk perspektiv på korleis medisinen fungerer i det moderne samfunnet. Den siste boka hans er ein analyse av korleis legemiddelindustrien har endra medisinen frå «old-style doctoring» til konsumentkapitalisme.

I dei seks kapitla skriv han om korleis legemiddelindustrien har tatt regien over klinisk forskning, om produksjon av vitskaplege artiklar, føreskrivingspraksis av legemiddel, kunnskapsproduksjon, marknadsføring og etikk. Forfattarens intensjon er å vise kva som har gått gale i medisinen, ikkje det som har vore ein suksess. Boka er først og fremst eit moralsk oppgjer med alle aktørane innan industri og medisin og ikkje primært eit systemperspektiv som kunne gi oss eit alternativ.

Og som dommedagsskrift over akademisk, vitskapleg amerikansk medisin er boka vellukka. Første kapittel omhandlar «The Guinea Pigs», friske personar som i mangel på gode alternativ sel seg inn som forsøkskaniner til forskningssentre for kliniske studier. Det er også blitt ein industri i USA. Det handlar gjerne om fattig, arbeidslaus ungdom, eventuelt ulovlege immigrantar som falbyr kroppen sin til medisinske eksperiment fordi det honoraret dei får, er deira måte å tene pengar på. Av mange grunnar er det vanskeleg å rekruttere ordinære pasientar eller frivillige forsøkspersonar til legemiddelutprøving. Forsøkskaniner med løn fordekt som honorar løyser rekrutteringsproblema, men ikkje kravet om at det skal vere pålitelege undersøkingar utan juks. Elliott beskriv korleis desse forsøkspersonane har organisert seg i aktivitetsgrupper, korleis dei jobbar for å få opp honoraret, og kor kreative dei blir i å sabotere forskningsvilkåra, til dømes ved å smugle og stele mat når dei er pålagt å vere fastande. Det er vanskeleg å få tillit til seriøsiteten i klinisk legemiddelutprøving dersom standarden er slik Elliott framstiller han.

På same måte omtaler han vitskaplege artikkelforfattarar som etter ein standardmal produserer manus som sentrale fagfolk låner namnet sitt ut til, slik at dei blir godskrivne som forfattarar, såkalla ghostwriters, og industrien får prestisjefylte publikasjonar.

Andre på industriens lønningsliste er legemiddelkonsulentane, opinionsdannarane, marknadsanalytikarane og bioetikarane, som alle lukkast bra med sitt prosjekt som stort sett består i å forføre legane til å løpe legemiddellindustriens ærend. Forfattaren gjer det ved å fortelje historie på historie om korleis legane er naive og let seg utnytte, gjerne i bytte mot banale goder eller pengar.

Som illustrasjon på ein ukultur er boka god. Kor representativ denne ukulturen er, kan ein ikkje vite. Tittelen gir assosiasjonar til mafia og krim. Og er det så ille i USA, der marknadskapitalismen visstnok er heilt einerådande, går medisinen ei mørk framtid i møte. Å jobbe i dette systemet er som å slåst med feiaren: Du kan ikkje unngå å bli skitten sjølv.

Som til dømes når Elliott sjølv skal delta på eit kritisk seminar om den farmasøytiske industrien. På veien opp til talarstolen får han det uunngåelege spørsmålet: Du har vel ikkje noko imot at eg takkar Jansens Pharmaceuticals for at dei er villige til å sponse din presentasjon?

\section{John Nessa}

Institutt for samfunnsmedisinske fag

Universitetet i Bergen

\section{Berørt av kreftsykdom}

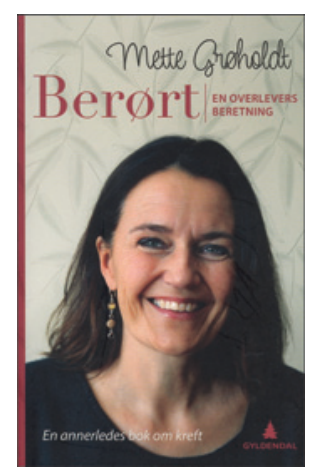

\section{Mette Grøholdt}

Berørt

En overlevers beretning. 251 s. Oslo:

Gyldendal, 2011. Pris NOK 349

ISBN 978-82-05-41190-6

Den selvbiografiske boken Berørt - en overlevers beretning handler om Mette Grøholdts møte med alvorlig livmorhalskreft. Grøholdt vant våren 2010 en konkurranse i Aftenposten med kronikken De stumme plagede (1). Her beskrev hun hvordan kreftoverleveren befinner seg i en tilstand hvor man ikke syk, men samtidig ikke frisk. Kronikken fikk stor oppmerksomhet, og Grøholdt, som er trebarnsmor og har bakgrunn som leder og rådgiver, har det siste året forelest for onkologer og annet helsepersonell om utfordringer ved å være kreftoverlever.

I boken beskriver Grøholdt forløpet gjennom kreftsykdommen, fra den første fasen alt før hun fikk diagnosen: «Min evne til å undertrykke smerter og symptomer var altfor stor. Jeg bet tenna sammen og kjempet meg videre mens kroppen ble stadig tyngre, trøttere og mer smertefull.» Videre skriver hun om hvordan hun opplevde kreftbehandling og store operasjoner. Den siste delen dreier seg om livet etter at hun er ferdigbehandlet. Hun beskriver en langvarig rehabiliteringsprosess - hvordan hun må lære seg å leve med kroppslige plager, endrede kroppsfunksjoner og vedvarende usikkerhet for tilbakefall. Hun konkluderer med at livet aldri blir som før, men avslutter med en positiv grunntone: «uansett hva som skjer vil jeg alltid være en overlever.»

Grøholdt skriver godt og innsiktsfullt om en smertefull reise, hvor hun berøres eksistensielt av sykdommen og forsoner seg med døden som en mulig utgang. Hun gir leseren innsikt i sentrale temaer som engstelse knyttet til kreftdiagnosen, frykt for døden, pårørendes reaksjoner og bivirkninger og følgetilstander etter kreftbehandlingen.

Boken er velskrevet og anbefales på det varmeste til alle som ønsker å lese en personlig og lærerik beretning om det å leve med alvorlig sykdom og livet med varige plager etter behandling.

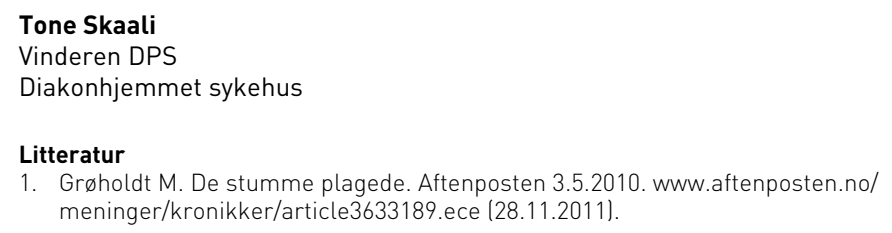

